\title{
SAMPLING STRATEGIES FOR TROPICAL FOREST NUTRIENT CYCLING STUDIES: A CASE STUDY IN SÃO PAULO, BRAZIL ${ }^{(1)}$
}

\author{
G. SPAROVEK $^{(2)}$ \& O. A. CAMARGO ${ }^{(3)}$
}

\begin{abstract}
SUMMARY
The precise sampling of soil, biological or micro climatic attributes in tropical forests, which are characterized by a high diversity of species and complex spatial variability, is a difficult task. We found few basic studies to guide sampling procedures. The objective of this study was to define a sampling strategy and data analysis for some parameters frequently used in nutrient cycling studies, i. e., litter amount, total nutrient amounts in litter and its composition ( $\mathrm{Ca}, \mathrm{Mg}, \mathrm{K}, \mathrm{N}$ and $\mathrm{P}$ ), and soil attributes at three depths (organic matter, $P$ content, cation exchange capacity and base saturation). A natural remnant forest in the West of São Paulo State (Brazil) was selected as study area and samples were collected in July, 1989. The total amount of litter and its total nutrient amounts had a high spatial independent variance. Conversely, the variance of litter composition was lower and the spatial dependency was peculiar to each nutrient. The sampling strategy for the estimation of litter amounts and the amount of nutrient in litter should be different than the sampling strategy for nutrient composition. For the estimation of litter amounts and the amount of nutrients in litter (related to quantity) a large number of randomly distributed determinations are needed. Otherwise, for the estimation of litter nutrient composition (related to quality) a smaller amount of spatially located samples should be analyzed. The determination of sampling for soil attributes differed according to the depth. Overall, surface samples $(0-5 \mathrm{~cm})$ showed high short distance spatial dependent variance, whereas, subsurface samples exhibited spatial dependency in longer distances. Short transects with sampling interval of 5-10 $\mathrm{m}$ are recommended for surface sampling. Subsurface samples must also be spatially located, but with transects or grids with longer distances between sampling points over the entire area. Composite soil samples would not provide a complete understanding of the relation between soil properties and surface dynamic processes or landscape aspects. Precise distribution of $P$ was difficult to estimate.
\end{abstract}

Index terms: Tropical forest, litter, soil nutrients, variability.

\footnotetext{
(1) Parte da Tese de Doutoramento do primeiro autor defendida na Escola Superior de Agricultura "Luiz de Queiroz", financiada pelo CNPq e apresentada na 3rd Conference on Forest Soils, Balikpapan. Recebido para publicação em Abril 1996 e aprovado em outubro de 1997.

(2) Professor do Departamento de Ciência do Solo da Escola Superior de Agricultura "Luiz de Queiroz", Caixa Postal 9, CEP 13418-900 Piracicàba (SP), Brasil. Bolsista do CNPq.

(3) Pesquisador da Seçāo de Pedologia do Instituto Agronômico de Campinas, Caixa Postal 28, CEP 13001-970 Campinas (SP), Brasil, Bolsista do CNPq.
} 


\title{
RESUMO: ESTRATÉGIAS PARA A AMOSTRAGEM EM ESTUDOS DE CICLAGEM DE NUTRIENTES EM FLORESTAS TROPICAIS: UM ESTUDO DE CASO EM SÃO PAULO, BRASIL.
}

\begin{abstract}
A amostragem precisa de atributos edáficos, biológicos ou microclimáticos em florestas tropicais, que apresentam elevada diversidade de espécies e variabilidade espacial complexa, é uma tarefa difícil. Encontram-se poucos estudos básicos sobre o assunto. Este estudo foi desenvolvido com o objetivo de definir uma estratégia de amostragem e análise de dados para alguns parâmetros utilizados, freqüentemente, em estudos de ciclagem de nutrientes, isto é, a quantidade, conteúdo em nutrientes e composição da serapilheira depositada ( $\mathrm{Ca}, \mathrm{Mg}, \mathrm{K}, \mathrm{Ne}$ $P)$ e atributos do solo em três profundidades (matéria orgânica, conteúdo de $P$, capacidade de troca de cátions e saturação por bases). Como área de estudo, foi escolhido um remanescente florestal, localizado no Oeste do Estado de São Paulo, e as amostras foram coletadas em julho de 1989. A quantidade total de serapilheira acumulada sobre o solo e o seu conteúdo em nutrientes apresentaram elevada variância espacialmente independente. A composição da serapilheira acumulada apresentou menor variância com dependência espacial peculiar a cada elemento. Assim, a amostragem para a determinaçāo da quantidade de serapilheira e para o seu conteúdo em nutrientes deve ser distinta daquela adotada para a avaliação de sua composição em nutrientes. Para estimar a quantidade e o conteúdo em nutrientes (relacionados com a quantidade), grande número de amostras distribuidas ao acaso é necessário. Visando a estimativa da composiçāo em nutrientes (relacionados com a qualidade), menor número de amostras de localização conhecida deve ser considerado. A definiçāo da amostragem para os atributos do solo foi distinta para as diferentes profundidades. De forma geral, as amostras superficiais $(0-5 \mathrm{~cm})$ apresentaram elevada variância com dependência espacial a pequenas distâncias, enquanto as camadas mais profundas apresentaram dependência espacial a distâncias maiores. Transeções curtas, com intervalos de amostragem de 5 a 10 m, devem ser utilizadas para a camada superficial. As amostras das camadas subsuperficiais também devem ser espacialmente referenciadas, mas tomadas em transeções ou malhas com distâncias maiores, cobrindo toda a área. Amostras compostas não possibilitariam a compreensāo completa das relação dos atributos químicos do solo com a dinâmica superficial ou posição no relevo $e$ material de origem. A distribuição precisa do P foi dificil de ser estimada.
\end{abstract}

Termos de indexação: floresta tropical, serapilheira, nutrientes do solo, variabilidade.

\section{INTRODUCTION}

Tropical forests are known to have a high number of species organized in a heterogeneous and complex ecosystem. Due to the interaction between the aboveground biota and the soil, via nutrient cycling processes, and an intense pedogenesis, some of this heterogeneity may be transferred to the soil (Golley et al., 1978). As the pedological and cycling processes are different for each nutrient, differences in variability for distinct nutrients and for other associated soil properties may occur. A complex variability distribution was observed for soil hydrological properties in Australian forests by Bonell et al. (1987), for litter production in a Sumatran forest by Schaik van \& Mirmanto (1985), for soil C, N and P in a Nigerian disturbed forest by Harvey et al. (1985) and for nutrient cycling parameters in a Brazilian semi-arid vegetation by Tiessen \& Santos (1989). Therefore, in nutrient cycling calculations or other modeling procedures the same sampling and data analysis scheme for all parameters will produce results with a wide range of accuracy or reliance causing an unworthy condition when they are considered as similar. The objective of this study was to develop guidelines for sampling and data analysis for commonly analyzed parameters in nutrient cycling studies, in order to help the collection of a reliable data set with similar degrees of precision. A more detailed report of this study can be found in Sparovek (1993).

\section{MATERIAL AND METHODS}

The study was carried out at the Agronomic Institute Research Station located in Pindorama, São Paulo, Brazil ( $48^{\circ} 55^{\prime} \mathrm{W}$ e $\left.21^{\circ} 13^{\prime} \mathrm{S}\right)$. The climate, according to Köppen's classification, is $A w$, with mean annual precipitation of $1,259 \mathrm{~mm}$. The soils within the $5.0 \mathrm{ha}$ research area were classified as Typic Kandiudalfs at the midslope and Plinthic Paleudults at the footslope near the drainage lines (Lepsch \& Valadares, 1976). The tropical semideciduous remnant forest was composed of trees with height ranging from 15 to $20 \mathrm{~m}$ and emergent trees of 25 to $30 \mathrm{~m}$. Approximately $20 \%$ of the species were deciduous in the dry winter season. The area has not been disturbed for at least 50 years.

Sixty four sampling points were located in the core area of the remnant forest in order to provide levels organized by a distance hierarchy $(7,25$ and $80 \mathrm{~m})$ covering 16 parcels with dimensions of 62.5 by $100 \mathrm{~m}$ (Figure 1). 


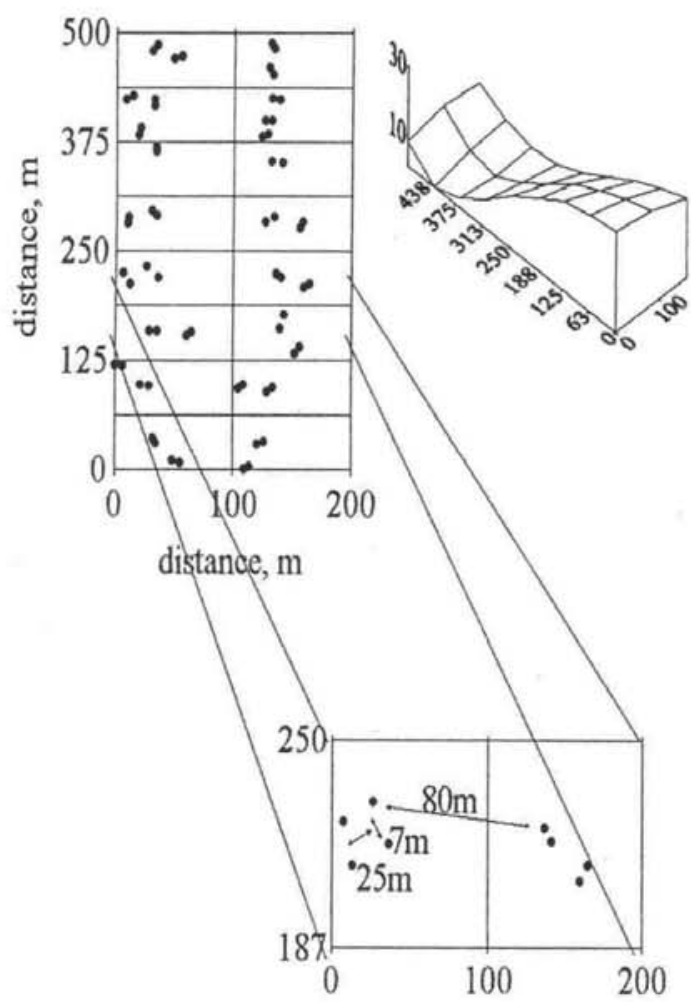

Figure 1. Sample collecting procedure in the study area and topographic profile. Dots are sampling points.

The coordinates of these points were previously selected to avoid sampling bias during field work. In each point litter was collected using a square frame of $0.25 \mathrm{~m}^{2}$, following the procedures suggested by Federer (1982). The material was oven dried $\left(60^{\circ} \mathrm{C}\right)$, separated in coarse $(>2.0 \mathrm{~mm})$ and fine $(<2.0 \mathrm{~mm})$ fractions, weighed and analyzed for total composition of $\mathrm{Ca}, \mathrm{Mg}, \mathrm{K}, \mathrm{N}$ and $\mathrm{P}$. The fine litter fraction, partially decomposed by organisms, has more contact with the mineral soil and the coarse fraction represented the fresh material. Nitrogen was determined by semimicro Kjeldahl, $\mathrm{P}$ by metavanadate colorimetry, $\mathrm{K}$ by flame emission photometry, and $\mathrm{Ca}$ and $\mathrm{Mg}$ by atomic absorption spectrophotometry following procedures described in Malavota et al. (1989). By multiplying the total amount of liter by its nutrient composition total nutrient amounts in the litter were calculated. At the same locations, soil samples were collected at 0-5, 5-25 and $60-80 \mathrm{~cm}$ depths. The air dried soil samples were sieved and analyzed for total organic matter (OM), determined by colorimetry after oxidation with sodium dichromate in sulfuric acid and resin extractable phosphorous $(\mathrm{P})$. Cation exchange capacity (CEC) based on the sum of resin extractable exchangeable $\mathrm{Ca}, \mathrm{Mg}, \mathrm{K}, \mathrm{Al}$ and $\mathrm{pH} 7.0$ extractable hydrogen, and base saturation (BS) were calculated according to Raij et al. (1987).
The statistical analysis included measurements of the mean, coefficient of variation, and the number of samples needed to estimate the mean value for a given percentage of error (Webster \& Oliver 1990). Hierarchical analysis of variance and semivariograms (Vieira et al. 1983) were computed. A detailed description of the equations and parameters used in the calculations can be found in Sparovek.(1993).

\section{RESULTS AND DISCUSSION}

\section{Litter}

The mean values of nutrient composition of litter fractions, the coefficient of variation and the number of samples necessary to estimate mean values within 5 and $10 \%$ of error are given in table 1 . The same parameters for litter amount and its total nutrient amounts are presented in table 2.

The coarse litter fraction had higher values of nutrient composition than the fine fraction and the coefficients of variance were greater in the fine fraction with exception of $\mathrm{K}$. The coefficient of variance for litter total amount and total nutrient amounts were higher than for its nutrient composition varying from $67 \%$ for total litter amount up to $142 \%$ for total amount of $\mathrm{K}$. Thus, the number of samples to estimate the mean with $10 \%$ of error was higher for litter amount and the total amount of nutrients (average of 209 samples) than for nutrient composition (average of 34 samples). The same trend was observed by Arp

Table 1. Mean values of nutrient composition of litter fractions, coefficients of variation and number of samples necessary to estimate the mean within 10 and $5 \%$ of error

\begin{tabular}{|c|c|c|c|c|}
\hline \multirow{2}{*}{ Nutrient } & \multirow{2}{*}{$\begin{array}{c}\text { Mean } \\
\text { composition }\end{array}$} & \multirow{2}{*}{$\begin{array}{l}\text { Coefficient } \\
\text { of variance }\end{array}$} & \multicolumn{2}{|c|}{ Number of samples for: } \\
\hline & & & $\begin{array}{l}10 \% \text { of } \\
\text { error }\end{array}$ & $\begin{array}{l}5 \% \text { of } \\
\text { error }\end{array}$ \\
\hline & $\mathrm{g} \mathrm{kg}^{-1}$ & $\%$ & & \\
\hline \multicolumn{5}{|c|}{ Coarse fraction $(>2.0 \mathrm{~mm})$} \\
\hline $\mathrm{Ca}$ & 24.8 & 21 & 12 & 18 \\
\hline $\mathrm{Mg}$ & 2.5 & 21 & 12 & 17 \\
\hline K & 2.1 & 40 & 45 & 65 \\
\hline $\mathrm{N}$ & 18.2 & 14 & 6 & 8 \\
\hline $\mathrm{P}$ & 0.7 & 26 & 19 & 27 \\
\hline
\end{tabular}

Fine fraction $(<2.0 \mathrm{~mm})$

\begin{tabular}{lrlll}
$\mathrm{Ca}$ & 12.5 & 49 & 67 & 95 \\
$\mathrm{Mg}$ & 1.6 & 35 & 34 & 49 \\
$\mathrm{~K}$ & 1.2 & 34 & 33 & 47 \\
$\mathrm{~N}$ & 12.4 & 36 & 35 & 51 \\
$\mathrm{P}$ & 0.6 & 47 & 62 & 89 \\
\hline
\end{tabular}


Table 2. Mean values of litter amount and the amount of nutrients in litter, coefficients of variation and number of samples necessary to estimate the mean within 10 and $5 \%$ of error

\begin{tabular}{|c|c|c|c|c|}
\hline \multirow[t]{2}{*}{ Parameter } & \multirow[t]{2}{*}{ Mean } & \multirow{2}{*}{$\begin{array}{l}\text { Coefficient } \\
\text { of variance }\end{array}$} & \multicolumn{2}{|c|}{ Number of samples for: } \\
\hline & & & $\begin{array}{l}10 \% \text { of } \\
\text { error }\end{array}$ & $\begin{array}{l}5 \% \text { of } \\
\text { error }\end{array}$ \\
\hline & $\mathrm{kg} \mathrm{ha}^{-1}$ & $\%$ & - & \\
\hline $\begin{array}{l}\text { Amount of litter } \\
>2.0 \mathrm{~mm}\end{array}$ & 5,900 & 81 & 184 & 264 \\
\hline $\begin{array}{l}\text { Amount of litter } \\
<2.0 \mathrm{~mm}\end{array}$ & 9,000 & 69 & 131 & 188 \\
\hline $\begin{array}{l}\text { Total amount of } \\
\text { litter }\end{array}$ & 15,000 & 67 & 127 & 182 \\
\hline Total amount of $\mathrm{Ca}$ & 309 & 79 & 173 & 249 \\
\hline $\begin{array}{l}\text { Total amount of } \\
\mathrm{Mg}\end{array}$ & 32 & 78 & 170 & 244 \\
\hline Total amount of K & 27 & 142 & 560 & 803 \\
\hline Total amount of $\mathrm{N}$ & 241 & 71 & 142 & 204 \\
\hline Total amount of $P$ & 10 & 82 & 186 & 267 \\
\hline
\end{tabular}

\& Krause (1984) in Canadian forests. The spatial dependency of the variance and the accumulated variance according to distance are presented in figure 2 for $\mathrm{P}$ and in figure 3 for $\mathrm{Ca}$.

The total amount of litter as well as its composition and total amounts of $\mathrm{N}$ and $\mathrm{K}$ did not show spatially dependent variance. Conversely, the values of composition in $\mathrm{P}$ resulted in linear semivariograms with low variance at small distances, whereas the composition in $\mathrm{Ca}$ presented exponential semivariograms with a smaller spatial dependency. The relation between variance and distance for $\mathrm{Mg}$ was similar as for $\mathrm{Ca}$. The total amount of nutrients did not reveal spatial dependency for any nutrient. Consequently, sampling for litter nutrient composition determination has to be different as for the estimation of litter amount or for the amount of nutrients retained in litter. The same sampling procedure for both would result in data with different degrees of precision.

With high variance and lack of spatial dependency, sampling schemes for estimation of litter amounts and the amount of nutrients retained in it (related to quantities) need a large number of randomly distributed determinations. In this study, the number of samples to estimate the mean within $10 \%$ of error varied from 131 for fine fraction litter amount up to 560 for total amount of However, 200 samples would be enough to determine the amount of all nutrients with a mean with an error less than $10 \%$ except for $\mathrm{K}$. Conversely, the estimation of nutrient composition values (related to quality) could be achieved with a smaller number of spatially located samples. However, the spatial dependency of variance was different for each nutrient. In order to combine the difference in variability of litter's nutrient composition and amounts in a unique sampling approach the following
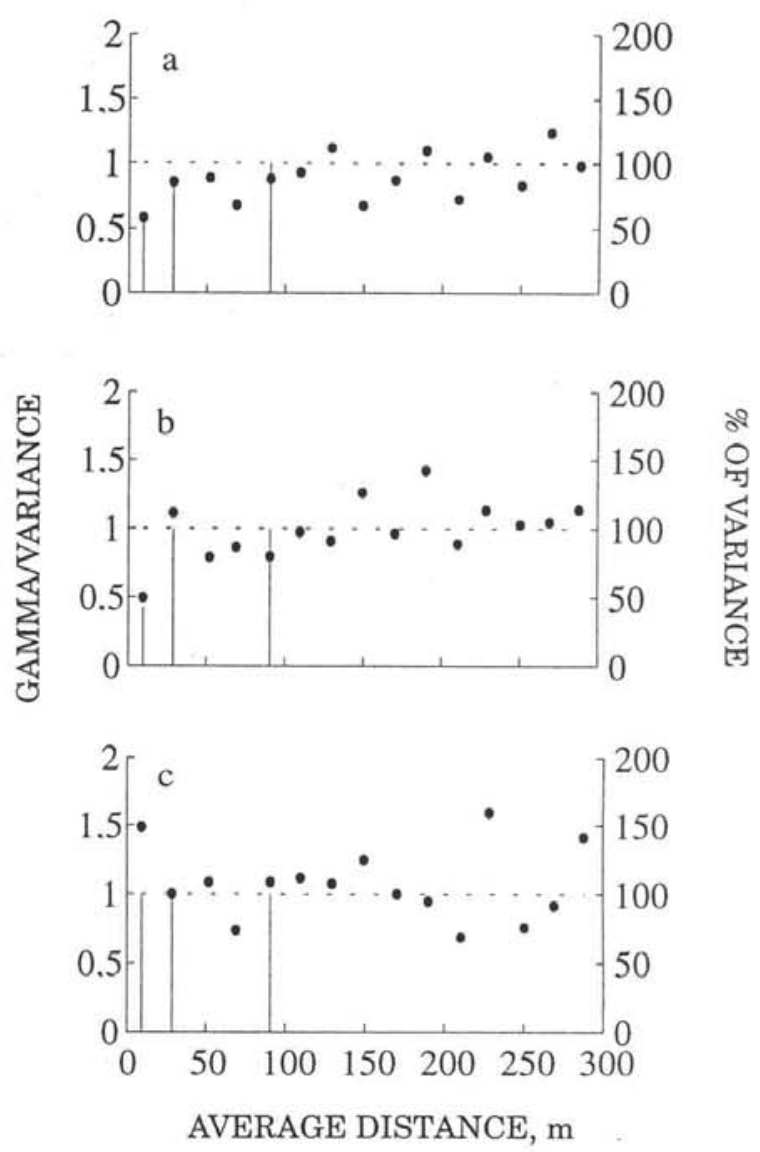

Figure 2. Normalized semivariance (dots) and accumulated variance (vertical lines) as related to distance for the composition of $\mathrm{P}$ in the litter coarse (a) and fine (b) fraction and for its total amount (c).

strategy can be recommended: a) previous definition of a grid or transect with small sampling intervals covering the entire study area; b) collection of samples for litter amount estimation in all positions and analysis of some of them for nutrient composition estimation; c) nutrient composition interpolations considering semivariogram. The number of samples needed to obtain reliable semivariograms may be different for each nutrient. A matching procedure analyzing some sampling positions, followed by the evaluation of results in order to define more specific sampling points for analysis until the desired results are obtained, may be a time and cost saving procedure. This can avoid oversampling and misevaluation that may occur if all parameters are sampled in the same way. These procedures are different from those suggested by Anderson \& Ingran (1989) as standard methods for tropical environments, which considered a fixed number of sampling points for both litter amount and composition determination. 

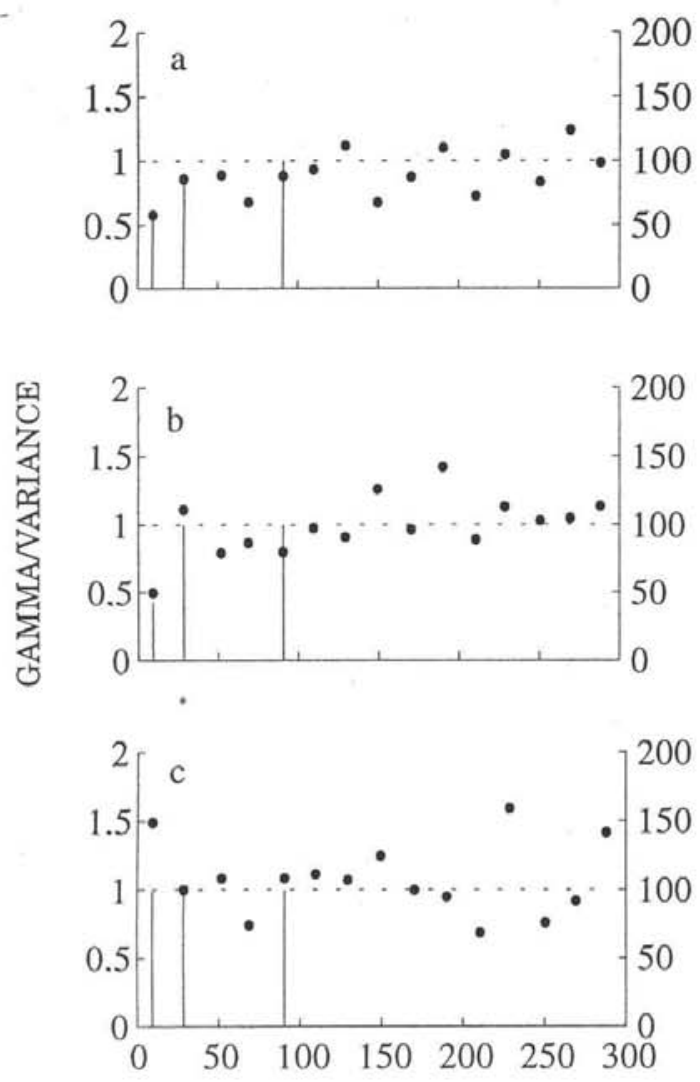

AVERAGE DISTANCE, $\mathrm{m}$

Figure 3. Normalized semivariance (dots) and accumulated variance (vertical lines) as related to distance for the composition of $\mathrm{Ca}$ in the litter, coarse (a) and fine (b) fraction and for its total amount (c).

\section{Soil}

The mean values of soil organic matter content, resin extractable $\mathrm{P}$ content, soil cation exchange capacity and base saturation at three depths are shown on table 3 . Coefficients of variation and the number of samples necessary to estimate mean values within error limits of 10 and $5 \%$ are also provided. Although the base saturation is not a parameter usually considered in nutrient cycling studies, it was used instead of the single exchangeable cations $(\mathrm{Ca}$, $\mathrm{Mg}$ and $\mathrm{K}$ ) because, in this experiment, it illustrated the overall trend of the individual cations. Consequently, the sampling and data analysis procedures presented are also valid for the individual cations. A more detailed discussion about the individual cations and the slight differences in relation to its individual variability can be seen in Sparovek (1993).
The values of the organic matter contents, extractable $\mathrm{P}$ and $\mathrm{CEC}$ were higher in the top layer of $0-5 \mathrm{~cm}$ than in the deeper ones. The same trend, with a smaller difference, was observed for base saturation, indicating higher contents of exchangeable cations in the surface layer. Similar observations were reported by Ewel et al. (1981) in a Costa Rican rain forest and Rodrigues (1991) in a Brazilian riparian forest in Ipeúna (SP). This may be attributed to the limited influence of the mineral soil in biological cycling of nutrients at this soil depth, if compared to deeper soil layers. The first few centimeters of soil are closely related to the bio-cycling processes reflecting its action and must therefore be analyzed separately from the underlying soil (Nye, 1961; Jordan \& Kline, 1972; Jordan, 1982; Vitousek \& Sanfor, 1986). This indicated the importance of considering a thin layer in soil sampling for nutrient cycling studies in forest ecosystems, thinner than the $0-20 \mathrm{~cm}$ layer usually sampled for soil fertility studies, or the first pedological A horizon that can extend to $100 \mathrm{~cm}$. The interaction between litter and a thin surface mineral soil layer, limiting most of the nutrients to leach deeply into the profile is the reason for nutrient accumulation. In a study with labeled elements in a tropical rain forest in Venezuela, Stark \& Jordan (1978) demonstrated that most of the nutrients that reach the surface soil due to throughfall or litter deposition are adsorbed directly beneath the litter layer. Failure to isolate this thin surface layer from the remaining mineral soil may induce a misunderstanding of this relationship.

The coefficients of variation were higher in the 0$5 \mathrm{~cm}$ layer than in the deeper ones except for base saturation. This may be related to intense surface deposition of $\mathrm{Ca}$ and $\mathrm{Mg}$ from deeper soil layers, considering that the parent material of these soils is highly saturated in Ca and Mg. Messenger et al. (1978) observed a similar condition for exchangeable aluminum variability in the surface soil layer after plantation of Pinus compared to the natural forest. The high aluminum content in the leaves and consequently in litter deposition was considered as responsible for the reduction in variability. The absorption by the forest of high amounts of $\mathrm{Ca}$ and $\mathrm{Mg}$, present in the deeper soil layers, and its deposition across the entire area, may cause homogeneity. The higher variability in the subsoil for this attribute may be related to pedogenic processes, considering different soil classes occur in the area.

The number of samples necessary to estimate the mean of soil nutrient parameters within $10 \%$ error was highly variable. Base saturation at the $0-5 \mathrm{~cm}$ depth could be estimated with 2 samples whereas 812 samples would be necessary for $P$.

The spatial dependency of the variance and the accumulated variance according to distance for the three sampling depths are illustrated for soil organic matter in figure 4, cation exchange capacity in figure 5 and base saturation in figure 6 . 
Table 3. Mean values for soil attributes in three depths, coefficient of variation, and number of samples to estimate the mean within 10 and $5 \%$ of error

\begin{tabular}{|c|c|c|c|c|c|}
\hline \multirow[t]{2}{*}{ Parameter $^{(1)}$} & \multirow[t]{2}{*}{ Depth } & \multirow[t]{2}{*}{ Mean } & \multirow{2}{*}{$\begin{array}{l}\text { Coefficient } \\
\text { of variance }\end{array}$} & \multicolumn{2}{|c|}{ Number of samples for: } \\
\hline & & & & $10 \%$ of error & $5 \%$ of error \\
\hline & $\mathrm{cm}$ & & $\%$ & & \\
\hline $\mathrm{OM}$ & $0-5$ & 58 & 45 & 57 & 81 \\
\hline $\mathrm{OM}$ & $5-25$ & 22 & 23 & 15 & 22 \\
\hline $\mathrm{OM}$ & $60-80$ & 12 & 22 & 14 & 20 \\
\hline $\mathrm{P}$ & $0-5$ & 11 & 171 & 812 & 1.164 \\
\hline P & $5-25$ & 3 & 75 & 157 & 226 \\
\hline P & $60-80$ & 1 & 126 & 444 & 636 \\
\hline CEC & $0-5$ & 170 & 58 & 93 & 133 \\
\hline CEC & $5-25$ & 70 & 34 & 32 & 46 \\
\hline CEC & $60-80$ & 50 & 32 & 28 & 40 \\
\hline BS & $0-5$ & 89 & 9 & 2 & 3 \\
\hline BS & $5-25$ & 75 & 19 & 10 & 14 \\
\hline BS & $60-80$ & 60 & 28 & 22 & 31 \\
\hline
\end{tabular}
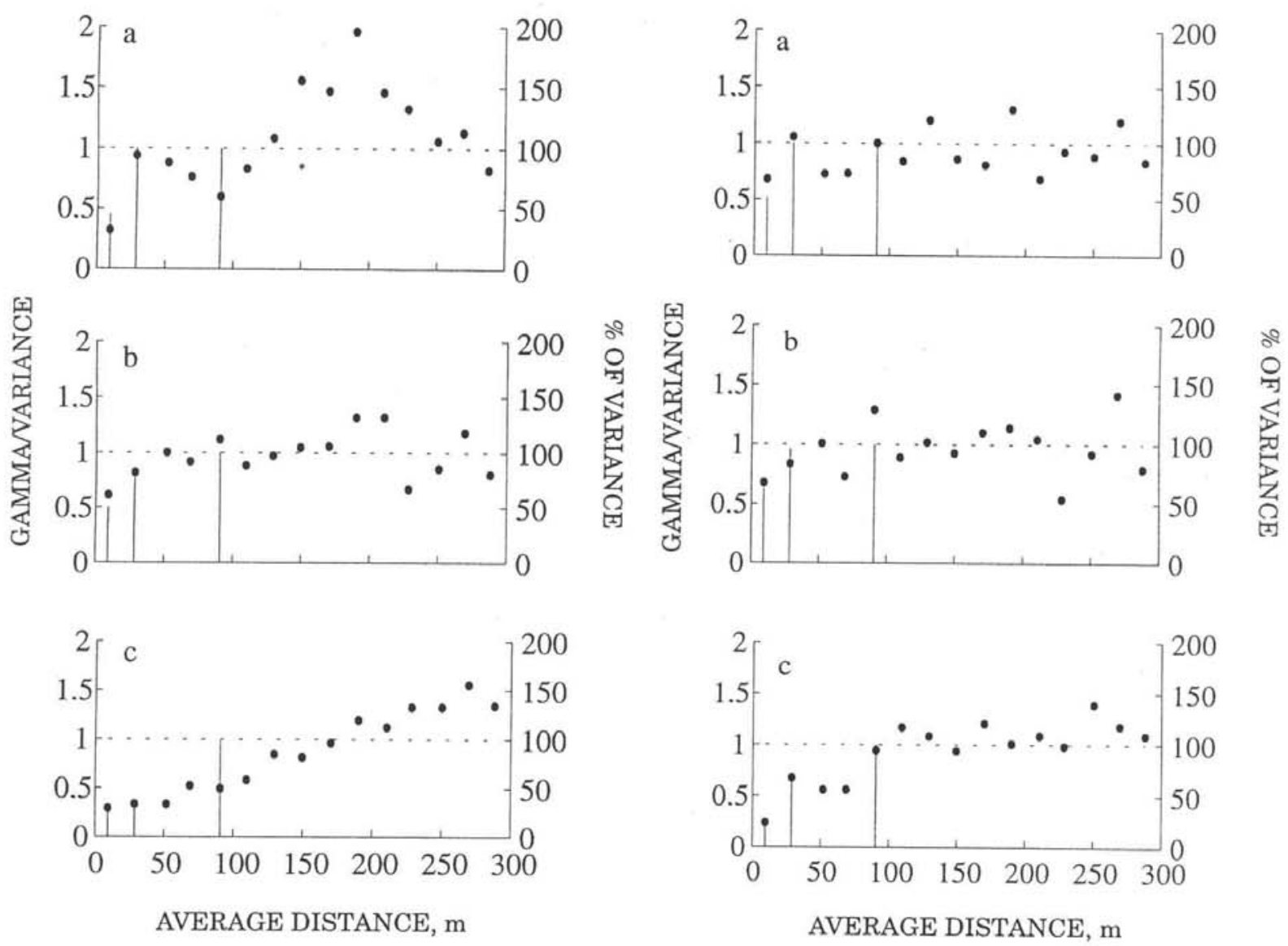

Figure 4. Normalized semivariance (dots) and accumulated variance (vertical lines) as related to distance for soil organic matter in the depth of 0-5 cm (a), $5-25 \mathrm{~cm} \mathrm{(b)} \mathrm{and} \mathrm{60-80} \mathrm{cm} \mathrm{(c).}$

Figure 5. Normalized semivariance (dots) and accumulated variance (vertical lines) as related to distance for soil cation exchange capacity in the depth of 0-5 cm (a), 5-25 cm (b) and 60-80 cm (c). 

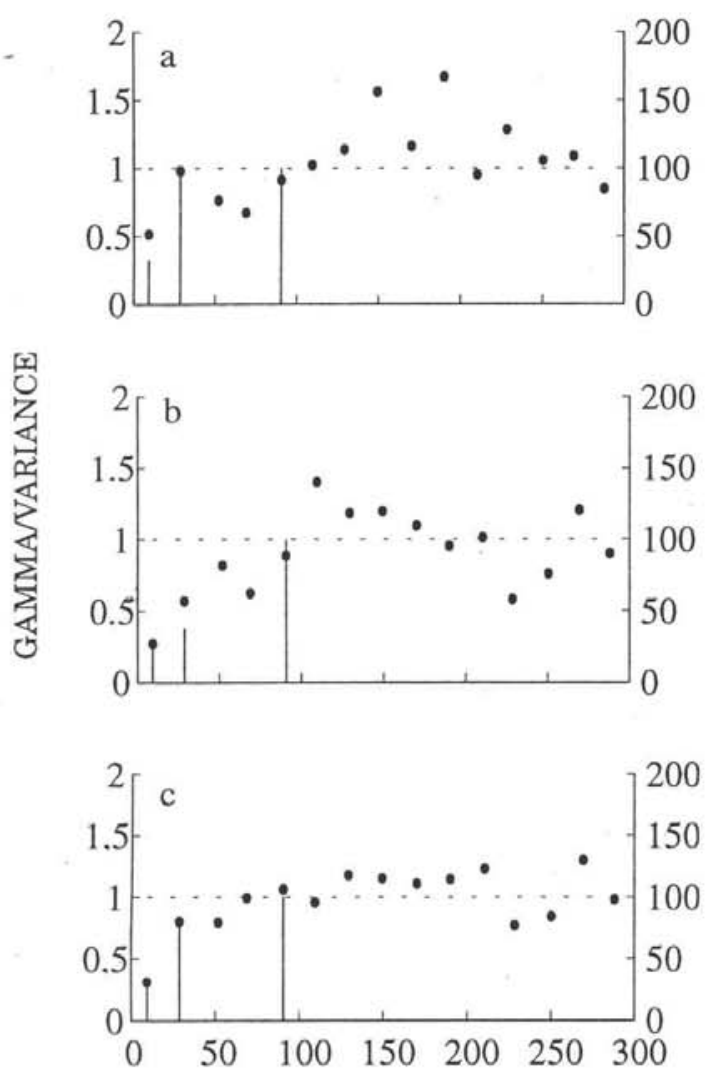

AVERAGE DISTANCE, $m$

Figure 6. Normalized semivariance (dots) and accumulated variance (vertical lines) as related to distance for soil base saturation in the depth of $0-5 \mathrm{~cm} \mathrm{(a),} 5-25 \mathrm{~cm}(\mathrm{~b})$ and $60-80 \mathrm{~cm}(\mathrm{c})$.

The variance of $\mathrm{P}$ was completely random. The variability of organic matter was different with depth. Surface samples had low variance at short sampling intervals, increasing rapidly with distance, and achieving total variance at $25 \mathrm{~m}$. For the $60-80 \mathrm{~cm}$ depth, the variance increased slowly with distance and the semivariogram was linear. A similar trend for CEC was probably due to the close relation between CEC and organic matter in these tropical soils. Base saturation showed a more uniform structure of the semivariograms with depth.

The sampling scheme for soil attributes should be specific for a considered depth and parameter. The variance and consequently the number of samples needed to estimate the mean, was higher at surface than at subsurface layer. Similarly the variance relation with distance was short $(<25 \mathrm{~m})$ at the depth of 0-5 cm. Therefore, the position of sampling points for surface soil layer should be related to trees or groups of trees rather than to soil morphology, taxonomic class or landscape position. Conversely, the subsurface samples showed a lower variance at larger distance and stronger relationship to pedological attributes. Composite soil samples would not provide a complete understanding of the relation between soil properties and surface dynamic processes or landscape aspects. However, some parameters may have a distinct trend. Base saturation had low variability while $\mathrm{P}$ was extremely variable and therefore difficult to estimate.

\section{CONCLUSIONS}

1. The variability of litter and soil attributes was different, justifying distinct sampling and data analysis procedures.

2. The lack of consideration of the systematic spatial variability and the underestimation of the casual variability of the individual parameters may compromise the accuracy of nutrient cycling studies in complex ecosystems.

\section{ACKNOWLEDGMENTS}

We offer a special thanks to Igo F. Lepsch, Quirijn de Jong van Lier and Álvaro Pires da Silva for revising the manuscript.

\section{REFERENCES}

ANDERSON, J.M. \& INGRAM, J.S.I. Tropical soil biology and fertility: a handbook of methods. Wallingford, $C A B$ International, 1989. 171p.

ARP, P.A. \& KRAUSE, H.H. The forest floor: lateral variability as revealed by systematic sampling. Can. J. Soil Sci., Ottawa, 64:423-437, 1984.

BONELL, M.; CASSELLS, D.S. \& GILMOUR, D.A. Spatial variations in soil hydraulic properties under tropical rainforest in northeastern Australia. In: PROCEEDINGS OF THE PRE-CONFERENCE OF THE INTERNATIONAL CONFERENCE ON INFILTRATION DEVELOPMENT AND APPLICATION. Hawaii, Proceedings. Hawaii, 1987. p.153-165.

EWEL, J.; BERISH, C.; BROWN, B., PRICE, N. \& RAICH, J. Slash and burn impacts on a Costa Rican wet forest site. Ecology, Brooklyn, 63:816-829, 1981.

FEDERER, C.A. Subjectivity in the separation of organic horizons of the forest floor. Soil Sci. Soc. Am. J., Madison, 46:10901093, 1982.

GOLLEY, F.B.; McGINNIS, J.T.; CLEMENTS, R.G.; CHILD, G.I, \& DUEVER, M.J. Ciclagem de minerais em um ecossistema de floresta tropical úmida. São Paulo, EDUSP, 256p., 1978.

HARVEY, I.M.; JUO, A.S.R. \& WILD, A. Soil organic C, N, S and P after forest clearance in Nigeria: mineralization rates and spatial variability. J. Soil Sci., London, 36:585-591, 1985.

JORDAN, C.F. \& KLINE, J.R Mineral cycling: some basic concepts and their application in tropical rain forest. Ann. Rev. Ecol. Syst., California, 3:33-49, 1972. 
JORDAN, C.F. The nutrient balance of an Amazonian rain forest. Ecology, Brooklyn, 63:647-654, 1982

LEPSCH, I.F. \& VALADARES, J.M.A.S. Levantamento pedológico detalhado da estação experimental de Pindorama, SP. Bragantia, Campinas, 35:13-40, 1976

MALAVOLTA, E.; VITTI, G.C. \& OLIVEIRA, S.A. de. Avaliação do estado nutricional das plantas. Princípios e aplicaçōes. Piracicaba, POTAFOS, 1989. 201p.

MESSENGER, A.S.; KLINE, J.R. \& WILDEROTTER, D. Aluminum biocycling as a factor in soil change. Plant Soil, The Hague, 49:703-709, 1978.

NYE, P.H, Organic matter and nutrient cycles under moist tropical forest. Plant Soil, The Hague, 13:333-346, 1961.

RAIJ, B. van; QUAGGIO, J.A.; CANTARELLA, H.; FERREIRA M.E.; LOPES, A.S. \& BATAGLIA, O.C. Análise química de solos para fins de fertilidade. Campinas, Fundação Cargill, 1987. 170 p.

RODRIGUES, R.R. Análise de um remanescente de vegetação natural às margens do Rio Passa Cinco, Ipeúna, SP Campinas, Instituto de Biologia/UNICAMP, 1991. 325p. (Tese de Doutorado)
SCHAIK van, C.P. \& MIRMANTO, E. Spatial variation in the structure and literfall of a Sumatran rain forest. Biotropica, Durham, 17:196-205, 1985.

SPAROVEK, G. Amostragem e análise de dados edafo-bioclimáticos de um remanescente florestal no Município de Pindorama (SP). Piracicaba, Universidade de São Paulo, ESALQ, 1993. 132 p. (Tese de Doutorado)

STARK, N.M. \& JORDAN, C.F. Nutrient retention by the root mat of an Amazonian rain forest. Ecology, Brooklyn, 59:434-437, 1978 .

TIESSEN, H. \& SANTOS, C.D. Variability of C, N and P content of a tropical semiarid soil as affected by soil genesis, erosion and land clearing. Plant Soil, The Hague, 119:337-341, 1989.

VIEIRA, S.R.; HATFIELD, J.L.; NIELSEN, D.R. \& BIGGAR, J.W, Geostatistical theory and application to variability of some agronomical properties. Hilgardia, Davis, 51:2-75, 1983.

VITOUSEK, P.M. \& SANFORD Jr., R.L. Nutrient cycling in moist tropical forest. Ann. Rev. Ecol.Syst., Palo Alto, 17:137-167, 1986.

WEBSTER, R. \& OLIVER, M.A. Statistical methods in soil and land resource survey. Oxford, Oxford University Press, 1990. $316 \mathrm{p}$ 